\title{
Early Holocene monsoon instability and climatic optimum recorded by Chinese stalagmites
}

Article

Accepted Version

Yang, X., Yang, H., Wang, B., Huang, L.-J., Shen, C.-C., Edwards, R. L. and Cheng, H. (2019) Early Holocene monsoon instability and climatic optimum recorded by Chinese stalagmites. The Holocene, 29 (6). pp. 1059-1067. ISSN 09596836 doi: https://doi.org/10.1177/0959683619831433 Available at https://centaur.reading.ac.uk/82615/

It is advisable to refer to the publisher's version if you intend to cite from the work. See Guidance on citing.

To link to this article DOI: http://dx.doi.org/10.1177/0959683619831433

Publisher: SAGE Publications

All outputs in CentAUR are protected by Intellectual Property Rights law, including copyright law. Copyright and IPR is retained by the creators or other copyright holders. Terms and conditions for use of this material are defined in the End User Agreement.

www.reading.ac.uk/centaur 
Central Archive at the University of Reading

Reading's research outputs online 


\title{
Early Holocene Monsoon Instability and Climatic Optimum Recorded by Chinese Stalagmites
}

\author{
Xunlin Yang ${ }^{1}$, Hong Yang ${ }^{1,2}$, Baoyan Wang ${ }^{1}$, Li-Jung Huang ${ }^{3,4}$, Chuan-Chou Shen ${ }^{3,4}$, R. Lawrence \\ Edwards $^{5}$, Hai Cheng, \\ 1. Chongqing Key Laboratory of Karst Environment, School of Geographical Sciences, Southwest University, \\ Chongqing, 400715, China \\ 2. Department of Geography and Environmental Science, University of Reading, Reading, Whiteknights, RG6 \\ $6 \mathrm{AB}, \mathrm{UK}$ \\ 3. High-Precision Mass Spectrometry and Environment Change Laboratory (HISPEC), Department of \\ Geosciences, National Taiwan University, Taipei 10617, Taiwan ROC \\ 4. Research Center for Future Earth, National Taiwan University, Taipei 10617, Taiwan ROC \\ 5. Department of Earth Sciences, University of Minnesota, Minneapolis, Minnesota 55455, USA. \\ 6. Institute of Global Environmental Change, Xi'an Jiaotong University, Xi' an 710049, China. \\ Corresponding author: X. Yang (xlyang@swu.edu.cn)
}




\begin{abstract}
The timing and duration of the Holocene East Asian summer monsoon (EASM) maximum and the interpretation of Chinese stalagmite $\delta^{18} \mathrm{O}$ records have long been disputed. Notably, interpretations of Holocene EASM variations are frequently based on a single record or study area and are often contradictory. In this study, we conducted stable isotope analyses of four Holocene stalagmites from Chongqing, southwest China. The results reveal differences in the timing of the Holocene EASM maximum, and to try to resolve the inconsistency we analyzed and statistically integrated a total of 16 Holocene stalagmite records from 14 caves in the EASM region. The resulting synthesized Holocene stalagmite $\delta^{18} \mathrm{O}\left(\delta^{18} \mathrm{O}_{\text {syn }}\right)$ record is in agreement with other EASM records, and confirms that stalagmite $\delta^{18} \mathrm{O}$ records are a valid indicator of EASM intensity, rather of local precipitation amount. The $\delta^{18} \mathrm{O}_{\mathrm{syn}}$ record shows that the EASM intensified rapidly from the onset of the early Holocene; notably, however, there were distinct EASM oscillations in the early Holocene, consisting of three abrupt millennial-scale events. This indicates that, contrary to several previous interpretations, the early Holocene EASM was unstable. Subsequently, during 8-6 kyr B.P., the EASM was relatively stable and strong, with the strongest monsoon occurring during 8-7 kyr B.P. This evidence of a stable and strong midHolocene EASM in eastern China is in accord with the classical view of a mid-Holocene Optimum in China.
\end{abstract}

Keywords: Stalagmite $\delta^{18} \mathrm{O}$; summer monsoon; millennial-scale events; Climatic Optimum; Early Holocene; East Asia

\title{
Introduction
}

The East Asian summer monsoon (EASM) is an important component of atmospheric circulation and plays a major role in global hydrological and energy cycles (An et al., 2000; Wang et al., 2005). It significantly affects the climate, environment and socioeconomic development of East Asia and other regions (Yang et al., 2013). However, the evolution of the EASM during the Holocene, especially the timing of the Holocene Optimum/EASM precipitation maximum, remains controversial (An et al., 2000; Chen et al., 2015, 2016; Goldsmith et al., 2017; Lu et al., 2013; Shi et al., 1994; Wang et al., 2005). Shi et al. (1994) summarized pollen, lake level and paleosol records from the EASM region and proposed that the climate of China during 7.2-6.0 kyr B.P. was warm, wet and stable - i.e. the Holocene Megathermal Maximum. A recent quantitative precipitation reconstruction from Gonghai Lake, in North China, showed that the EASM maximum occurred during the mid-Holocene (7.8-5.3 kyr B.P.) (Chen et al., 2015), supporting the concept of a mid-Holocene Optimum in China. However, a sequence of eutrophic peat/mud sediments from Dahu Lake, in southern China, revealed a warm and humid interval during 10.0-6.0 kyr B.P. which supported the interpretation of an early Holocene maximum (Zhou et al., 2004). In addition, a lake level reconstruction from Lake Dali (Goldsmith et al., 2017), at the edge of the monsoon region in North China, indicated the occurrence of very high lake levels in the early and mid-Holocene; and in addition there was a significant negative correlation between lake level and the stalagmite $\delta^{18} \mathrm{O}$ record for China, which indicates that stalagmite $\delta^{18} \mathrm{O}$ records in 
China reflect changes in summer monsoon intensity /monsoon precipitation. However, Chen et al. (2016) and Yang et al. (2014) suggested that the stalagmite record supported an early Holocene Optimum/EASM maximum - in contrast to traditional EASM or EASM precipitation records from northern China (Lu et al., 2013; Xiao et al., 2008) - and they questioned the reliability of stalagmite records as a proxy for changes in EASM intensity/precipitation (Chen et al., 2016; Dayem et al., 2010; Francesco et al., 2011; Maher, 2008; Tan, 2009). Based on the assumption that stalagmite $\delta^{18} \mathrm{O}$ records directly reflect EASM intensity, several researchers have reconstructed the EASM evolution on various timescales and proposed causal mechanisms (e.g. Cheng et al., 2012, 2016; Wang et al., 2005, 2008). More recently, however, it was proposed that stalagmite records in China are indicators of water vapor source rather than EASM intensity (Chen et al., 2016; Francesco et al., 2011; Maher, 2008; Tan, 2009).

The forgoing summary highlights that the controversy regarding the pattern of Holocene climate change in China focuses on the early-middle Holocene, and that the contrasting interpretations of the stalagmite $\delta^{18} \mathrm{O}$ record in China are so far unresolved. Given the possibility of regional differences in the processes of carbonate deposition, it is important to analyze stalagmite $\delta^{18} \mathrm{O}$ records from multiple sites. Accordingly, in this study, four Holocene stalagmite records from three caves (Jinfo, Heifeng and Shizi) in Chongqing, southwest China, were collected and analyzed. We then combined the results from these caves with an additional 12 stalagmite records from the EASM region of China and use them to discuss the pattern of earlymiddle Holocene climate change in eastern China. In addition, by comparing the stalagmite records with other proxy records, we further assess the climatic significance of stalagmite $\delta^{18} \mathrm{O}$ records in East Asia.

\section{Materials and methods}

[Figure 1]

Four Holocene stalagmites were collected from three caves in Chongqing (Fig. 1), in the upper reaches of the Yangtze River, in southwest China. The region has a typical EASM climate, with an average annual precipitation of $1125 \mathrm{~mm}$, which occurs mainly from May to September; summer precipitation comprises up to about $70 \%$ of the total annual precipitation. Stalagmite QM09, with a length of $480 \mathrm{~mm}$, is from Shizi Cave (29 $40^{\prime} 56^{\prime \prime} \mathrm{N}, 106^{\circ} 17^{\prime} 17^{\prime \prime}$ E, altitude $401 \mathrm{~m}$ ) located in Qingmuguan Town, northwest of Chongqing City. The Qingmuguan karst system consists of carbonate of the lower Triassic Jialingjiang Formation with a thickness exceeding $600 \mathrm{~m}$. Exposed at the anticlinal axis, it is the oldest stratum at the site and is the main body of the mountain. Lithologically, the formation is mainly composed of grey-colored thick massive limestone, dolomite limestone and brecciaous limestone. Shizi Cave is a small underground river cave system. Stalagmite QM09 was collected from the rock wall $50 \mathrm{~m}$ from the entrance of the cave; a total of $24{ }^{230}$ Th dates and 315 stable 
isotope measurements were obtained, with an average resolution of $30 \mathrm{yr}$. Stalagmites J12 (length $395 \mathrm{~mm}$ ) and J13 (length $210 \mathrm{~mm}$ ) were collected from Jinfo Cave $\left(29^{\circ} 01^{\prime} 00^{\prime \prime} \mathrm{N}, 107^{\circ} 10^{\prime} 45^{\prime \prime}\right.$ E, altitude $\left.2114 \mathrm{~m}\right)$, in southeast Chongqing, specifically in Mt. Jinfo of Nanchuan. The study site is located on the southeastern margin of Sichuan Basin, along the northern margin of the Yun-Gui Plateau and at the northern end of the Dalou Mountains. The uppermost rock unit comprising Mt. Jinfo is Permian limestone, and a huge and complex underground cave system has developed within this unit. The cave exhibits a corridor planar form and is $2800 \mathrm{~m}$ long, 8-25 m wide and generally 8-12 m high. Stalagmites J13 and J12 were collected at locations $100 \mathrm{~m}$ and $1200 \mathrm{~m}$ from the entrance of the cave, respectively. Twenty-eight ${ }^{230} \mathrm{Th}$ ages and 432 stable isotope measurements were obtained from stalagmite J13, with an average resolution of $27 \mathrm{yr}$. In this study, only Holocene data are considered, and the length of the Holocene interval of stalagmite J12 is about $70 \mathrm{~mm}$. Eight ${ }^{230} \mathrm{Th}$ dates and 161 stable isotope measurements were obtained from stalagmite J12, with an average resolution of $50 \mathrm{yr}$. Stalagmite HF01 (length $130 \mathrm{~mm}$ ) was collected $10 \mathrm{~m}$ from the entrance of Heifeng Cave (altitude $2132 \mathrm{~m}$ ). Heifeng Cave is $1200 \mathrm{~m}$ from Jinfo Cave and its geological background is similar to that of Jinfo Cave. Heifeng Cave has a dendritic shape, consisting of the main channel of the underground river and two large caverns that expand along the northeastward fracture. Thirty ${ }^{230} \mathrm{Th}$ ages and 325 stable isotope measurements were obtained from Stalagmite HF01, with an average resolution of $30 \mathrm{yr}$. The stalagmites from Jinfo Mountain are dense and contain high uranium concentrations. There is no evidence of re-crystallization, erosion or hiatuses and hence they are highly suited to precise ${ }^{230} \mathrm{Th}$ dating. The stalagmites collected from Shizi Cave, in the Qingmu Guan Mountains, typically have low uranium concentrations which are likely to result in a larger dating error. Oxygen isotope measurements were made with a Finnigan Delta V Plus in Southwest University, China, and are reported as $\delta^{18} \mathrm{O}(\%)$ with respect to the Vienna Pee Dee Belemnite standard (V-PDB). An international standard, NBS-19, was used to confirm that the $1 \sigma$ measurement uncertainty was better than $\pm 0.1 \%$. Measurements of ${ }^{230}$ Th for stalagmites J12, J13 and Hf01 were made with a Thermo-Finnigan Neptune multi-collector inductively coupled plasma mass spectrometer in the Institute of Global Environmental Change, Xi'an Jiaotong University; and measurements of ${ }^{230} \mathrm{Th}$ for stalagmite QM09 were made in the High-Precision Mass Spectrometry and Environmental Change Laboratory, Department of Geosciences, National Taiwan University, using integrated MC-ICP-MS analysis. The analytical uncertainty of the dating was equal to or less than $1 \%(2 \sigma)$. The age model for three stalagmites without hiatuses (QM09, J13 and Hf01) were established by polynomial fitting; and the age model for stalagmite J12 (which has a hiatus) was done by linear interpolation. The methods used for ${ }^{230} \mathrm{Th}$ dating are described in Cheng et al. (2013) and Shen et al. (2012).

We also collected 12 published stalagmite Holocene records from the EASM region (Fig. 1). These records have a high-precision U-Th chronology covering most of the Holocene. To facilitate data analysis and integration, the original stalagmite records were interpolated to a common time step using AnalySeries 2.0.4 
(Paillard et al, 1996). The resolution of the new time series was $50 \mathrm{yr}$ and the $\delta^{18} \mathrm{O}$ data was normalized using equation (1), below:

$$
x=\frac{x_{i}-x_{\min }}{x_{\max }-x_{\min }}
$$

Here, $x$ is the normalized value, $x_{i}$ are interpolated isotope values and $x_{\min }$ and $x_{\max }$ are the minimum and maximum values of the individual interpolated data series. The normalized data fall within the range of $[0,1]$. To facilitate comparison of records, the values were adjusted using the following equation:

$$
\delta^{18} \mathrm{O}_{i}=x-1
$$

Thus, the $\delta^{18} \mathrm{O}_{i}$ values were within the range of $[0,-1]$, in accordance with the original data series. To minimize the impact of regional differences, differences in the process of signal acquisition, and analytical errors, the $\delta^{18} \mathrm{O}_{i}$ records were used to produce a stacked synthesized record $\left(\delta^{18} \mathrm{O}_{\text {syn }}\right)$. This was obtained by averaging all the values at each sampling point for the 16 Holocene stalagmite $\delta^{18} \mathrm{O}$ records from 14 caves in the EASM region. In addition, we used a partitioning synthesis approach to assess the reliability of the synthetic record $\left(\delta^{18} \mathrm{O}_{\text {syn }}\right)$. First, we divided the eastern monsoon region of China into two sub-regions: north and south, with the boundary corresponding to the Qinling-Huaihe River. We then synthesized the stalagmite records for the south and north sub-regions, separately. Finally, we calculated the arithmetic average of the synthesized data for the two sub-regions to produce another synthesized record $\left(\delta^{18} \mathrm{O}_{\mathrm{S}+\mathrm{N}}\right)$.

\section{Results and discussion}

\section{Stalagmite $\delta^{18} \mathrm{O}$ records from Chongqing, southwest China}

Following previous research (Cai et al., 2010, 2012; Cheng et al., 2012, 2016; Dong et al., 2010; Wang et al., 2005, 2008), our initial premise was that stalagmite $\delta^{18} \mathrm{O}$ records are proxies of EASM intensity, and our results enable this assumption to be tested. Following the sub-division of the Holocene by Walker (2014), 8 kyr B.P. and 4 kyr B.P. are taken as the respective boundaries of the early-mid Holocene and the mid-late Holocene.

[Figure 2]

In the HF01 stalagmite record from Heifeng Cave in Chongqing (Fig. 2), the $\delta^{18} \mathrm{O}$ values are more negative during 11.5-10.0 kyr B.P., indicating the gradual strengthening of EASM from the beginning of the Holocene. The values are moderately negative and relatively stable during 10.0-8.5 kyr B.P., indicating a comparatively stable EASM; and they are more positive during 8.5-8.0 kyr B.P., indicating a weak EASM event. The values are the most negative during 8.0-7.0 kyr B.P., in the mid-Holocene, reflecting the strongest EASM during the 
entire Holocene. In the J13 stalagmite record from Jinfo Cave, the $\delta^{18} \mathrm{O}$ values are more negative during 10.2$9.2 \mathrm{kyr}$ B.P., and subsequently there is a weak monsoon event lasting for about $1 \mathrm{kyr}$, indicating an unstable EASM. During 8.1-7.0 kyr B.P., in the mid-Holocene, there is another interval of more negative values. Thus, the $\mathrm{J} 13 \delta^{18} \mathrm{O}$ record suggests a strong EASM in both the early and the mid-Holocene, with both intervals having a similar duration.

In stalagmite $\mathrm{J} 12$ from Jinfo Cave, there is a 2 kyr hiatus in the early Holocene; during 8.0-6.5 kyr B.P., the $\delta^{18} \mathrm{O}$ values are stable and more negative. In stalagmite QM09 from Shizi Cave, there is also a hiatus in the early Holocene; during 9.2-8.0 kyr B.P. the $\delta^{18} \mathrm{O}$ values oscillate markedly, and during 8.0-6.0 kyr B.P. they are relatively negative, indicating a strong EASM.

From the foregoing, it can be concluded that the Holocene stalagmite $\delta^{18} \mathrm{O}$ records from the three caves in Chongqing show a similar trend of variation on the orbital scale, which is in accord with the trend of changing summer insolation in the Northern Hemisphere. On centennial-millennial scales, however, there are substantial differences; for example, the timing and duration of the interval of stable and more negative $\delta^{18} \mathrm{O}$ values for each cave varied during the Holocene. Furthermore, although Jinfo Cave is only $1200 \mathrm{~m}$ from Heifeng Cave, their Holocene climatic records are different on the centennial-millennial scale, which may be attributed to factors other than climate change (Fairchild et al., 2006).

\section{Stalagmite $\delta^{18} \mathrm{O}$ records from elsewhere in China}

The variations in the $\delta^{18} \mathrm{O}$ records of the cave stalagmites on a centennial-millennial scale may be influenced by a complex range of factors. In addition to climatic factors (e.g. precipitation, temperature and water source) local factors (e.g. seepage path, karst fissure water, convective cave ventilation and kinetic fractionation) can also influence stalagmite $\delta^{18} \mathrm{O}$ values on a short timescale (Fairchild et al., 2006). All these factors may filter or obscure a common climatic signal within stalagmite records, leading to differences on decadal, centennial and millennial scales (Tan et al., 2009; Zhang et al., 2008). Clearly, therefore, multiple stalagmite records from different caves are needed to isolate a common climatic signal.

The HS4 stalagmite $\delta^{18} \mathrm{O}$ record from Heshang Cave (Hu et al., 2008) (Fig. 3), also in the upper reaches of the Yangtze River, shows a similar trend to the records from Shizi Cave. The HS4 record contains an asymmetrical ' $\mathrm{W}$ '-shaped oscillation during 8.8-8.0 kyr B.P., with more stable and negative values during 8.05.0 kyr B.P. The stalagmite $\delta^{18} \mathrm{O}$ records from Nuanhe Cave, in North China (Wu et al., 2011), exhibit substantial oscillations during 10.4-8.2 kyr B.P., in the early Holocene, and more stable and negative values during 8.2-5.6 kyr B.P., indicating a strong EASM. The records from Lianhua Cave in Shanxi Province (Dong et al., 2015) contain substantial oscillations throughout the early Holocene, indicating the occurrence of a series of centennial-millennial-scale abrupt events; subsequently, during 8.0-6.3 kyr B.P., the values are more stable and negative, indicating a strong EASM. The record from Jiuxian Cave (Cai et al., 2010) exhibits an initial negative inflection at around $11.5 \mathrm{kyr}$ B.P., in the early Holocene; this is followed by a positive $\delta^{18} \mathrm{O}$ 
trend lasting for about $2 \mathrm{kyr}$, and then by more negative values during 9.0-4.0 kyr B.P. The record from Sanbao Cave (Dong et al., 2010) is relatively uniform throughout the Holocene. The record from Lianhua cave (Zhang et al., 2013) in Hunan Province, southern China, is comparatively negative in the early Holocene, with the most negative values during 9.5-7.0 kyr B.P. At Dongge Cave (Wang et al., 2005), the record rapidly becomes negative at the beginning of the early Holocene (11.6-11.0 kyr B.P.), indicating a strengthening of the EASM; and during 11.0-9.0 kyr B.P. there are a series of oscillations suggesting intervals of a weakened monsoon which lasted for 10-100 yr. During two intervals, 8-7 kyr B.P. and 9.0-8.2 kyr B.P., the values are stable and negative.

[Figure 3]

\section{Stacked stalagmite record $\left(\delta^{18} \mathbf{O}_{\text {syn }}\right)$}

[Figure 4]

Comparison of the various stalagmite $\delta^{18} \mathrm{O}$ records from the three caves in Chongqing, and from sites elsewhere in China, reveals differences in the timing and duration of intervals of stable, negative values within the Holocene. Clearly, therefore, no individual cave stalagmite $\delta^{18} \mathrm{O}$ record can be taken to represent variations in the EASM on the centennial-millennial scale. The two synthesized records $\left(\delta^{18} \mathrm{O}_{\text {syn }}\right.$ and $\left.\delta^{18} \mathrm{O}_{\mathrm{S}+\mathrm{N}}\right)$ have a very consistent trend and they are strongly correlated $(\mathrm{R}=0.99)$. To further evaluate the reliability of the synthesized records, we compared them with the results of principal components analysis of 7 integrated Holocene stalagmite records (Fig. 3b, Fig. 3d, Fig. 3e, Fig. 3h, Fig. 3k, Fig. 31 and Fig. 3p). The results show that the first component (PC1) captures a large proportion of the variance (78.8\% of the total) and the plot of the sample scores on PC1 is well correlated with the synthesized record $\left(\delta^{18} \mathrm{O}_{\text {syn }}\right)(\mathrm{R}=0.99)$. This suggests that the synthesized data is reliable.

[Figure 5]

These records, which are illustrated in Fig.5, emphasize the common characteristics of the set of Holocene stalagmite records from China. On the orbital timescale, the variation of the synthesized record $\left(\delta^{18} \mathrm{O}_{\text {syn }}\right)$ clearly tracks changes in Northern Hemisphere summer insolation. Specifically, the record exhibits a gradual trend of increasingly negative values in the early Holocene. Superimposed on this trend are three pronounced negative shifts followed by a positive shift. During 11.6-11.0 kyr B.P., the values rapidly become negative, 
with a moderate negative peak at $11.0 \mathrm{kyr}$ B.P., indicating that the EASM gradually strengthened at the beginning of the Holocene. Subsequently, at around $11.0 \mathrm{kyr}$ B.P., there is a 'W'-shaped oscillation which lasted for about $0.5 \mathrm{kyr}$, indicating a weak EASM event. In addition, there are two positive events centered at 9.4 kyr B.P and 8.2 kyr B.P., each of which lasted for about 0.3-0.5 kyr. These short-term features suggest an unstable EASM during the early Holocene. These weak monsoon events coincide with three cold events evident in the Greenland NGRIP $\delta^{18} \mathrm{O}$ paleotemperature record, at $11.0 \mathrm{kyr}$ B.P., $9.3 \mathrm{kyr}$ B.P. and $8.2 \mathrm{kyr}$ B.P., corresponding to North Atlantic cold events 5, 6 and 8 (Bond et al., 2001; Johnsen et al., 2001). This indicates the covariation of Asian monsoonal fluctuations with climate change at high latitudes of the Northern Hemisphere. The $\delta^{18} \mathrm{O}_{\text {syn }}$ record is relatively stable with moderately negative values during 8.0-6.0 kyr B.P., indicating a strong EASM. The values are the most negative during 8.0-7.0 kyr B.P., in the mid-Holocene, indicating that the strength of the EASM was at a maximum. During 8.0-6.0 kyr B.P., the mid-Holocene, the values are $9.31 \%$ more negative than in the early Holocene (11.0-8.0 kyr B.P.).

Two major observations can be drawn from the foregoing. First, the early Holocene EASM was unstable, with several abrupt fluctuations; and second, the EASM was stronger in the mid-Holocene than in the early Holocene. These findings differ from the concept of an early Holocene maximum based on stalagmite records proposed by Chen et al. (2016). Therefore, in terms of the intensity, stability and duration of the EASM, the stalagmite records exhibit a classical mid-Holocene Optimum. Vaks et al. (2013) and Wang et al. (2004) suggested that phases of stalagmite growth likely correspond to intervals of high rainfall. Our results indicate the continuous growth of stalagmites in all 14 caves during 8.0-5.0 kyr B.P. (Fig. 3 and Fig. 4), and in contrast, few stalagmites in these caves grew continuously in the early Holocene and in the later Holocene. This indicates that in general in the EASM region was humid during the mid-Holocene.

\section{Comparison of the synthesized stalagmite record $\left(\delta^{18} \mathrm{O}_{\text {syn }}\right)$ with other monsoon records}

\section{[Figure 6]}

A comparison of the $\delta^{18} \mathrm{O}_{\text {syn }}$ record with other Holocene records of EASM/precipitation (Fig. 6) reveals similar trends of variation. The Hongyuan peat $\delta^{13} \mathrm{C}$ record from the eastern Tibetan Plateau indicates that the Asian summer monsoon was unstable, with three strong/weak events in the early Holocene (Hong et al., 2003); however, the Asian summer monsoon was relatively stable and strong during 8.0-5.0 kyr B.P. The East Asian summer monsoon index (SMI) from Lake Qinghai indicates two intervals of a strengthened EASM in the early Holocene, each of which persisted for only $\sim 0.5 \mathrm{kyr}$ (An et al., 2012). The lake-level history of Lake Dali (Goldsmith et al., 2017) suggests that the level increased rapidly in the early Holocene, during which there were two brief episodes of moderate lake-level rise, and that subsequently the lake level fell rapidly; this indicates an unstable EASM in the early Holocene with significant lake level oscillations. The highest lake level was during 8.0-5.8 kyr B.P., in the mid-Holocene, indicating that the EASM was at its maximum 
intensity at that time, which is supported by a pollen record from Lake Dali (Xiao et al., 2008). The $\delta^{18} \mathrm{O}_{\text {syn }}$ record exhibits a significant inverse relationship (Fig. 7, $\mathrm{R}=-0.64, \mathrm{P}<0.001, \mathrm{~N}=232$ ) with a recent precipitation record from Gonghai Lake in northern China (Chen et al., 2014). The pollen record from Gonghai Lake suggests that EASM rainfall increased gradually from the beginning of Holocene; during 10.2-9.6 kyr B.P. there was a moderate EASM strengthening and a humid stage; during 9.6-8.0 kyr B.P. there was a transient weakening of the EASM; and the highest precipitation occurred during 8.0 5.3 kyr B.P. in the mid-Holocene. This latter interval coincides with an interval of strong EASM indicated by the $\delta^{18} \mathrm{O}_{\text {syn }}$ record.

Based on the aforementioned observations, it is apparent that the stalagmites records and other monsoon/ precipitation records based on lake sediments (An et al., 2012; Chen et al., 2014; Goldsmith et al., 2017), peats (Hong et al., 2003) and paleosols (Wang et al., 2014) exhibit a similar trend during the Holocene. This implies that when the monsoon was relatively strong, a more humid period occurred in the eastern monsoon region of China. Although Chinese stalagmite records exhibit a good consistency across a substantial part of China on the orbital scale (Yang et al., 2014), there are substantial differences in precipitation at different localities (Daye et al., 2010). Stable isotope records of stalagmites from Wanxiang Cave (Zhang et al., 2008) and Dayu Cave (Tan et al., 2015) reveal a good correlation with local precipitation, but the results from Heshang Cave are inconsistent with the variations of both local precipitation and a drought-wetness index (Hu et al., 2008; Tan, 2009; Xie et al., 2013). The climate simulation results of Pausata et al. (2011) suggest a possible scenario in which, in the eastern monsoon region of China, a negative (positive) shift in precipitation $\delta^{18} \mathrm{O}$ values on a millennial timescale mainly reflects strong (weak) Asian summer monsoon events as a whole, rather than the amount of local rainfall in the individual site. Considering the complex relationship between monsoon intensity and local precipitation (Tan, 2009; Zhang et al., 2018), we cannot simply interpret $\delta^{18} \mathrm{O}$ variations of Chinese stalagmites as local precipitation, but rather as a mean state of summer monsoon intensity, or integrated moisture transport (Cheng et al. 2006; 2012; Johnson and Ingram 2004).

[Figure 7]

The early Holocene changes in the EASM on a centennial-millennial scale recorded by geological archives (e.g. loess, lake sediments and stalagmites) are generally different. The pollen record from Qinghai Lake (Shen et al., 2005) does not show significant EASM events, but two episodes of intensified/weakened EASM are evident in the EASM Index from Lake Qinghai (An et al., 2012); in addition, a millennial-scale decrease of the EASM in the early Holocene is evident in the pollen record from Gonghai Lake (Chen et al., 2015). There are also large differences in the number and magnitude of abrupt climatic events in the early Holocene recorded by different stalagmite records. The stalagmite records from Lianhua Cave in northern China suggest at least four episodes of weakened EASM in the early Holocene (Dong et al., 2015), and there is least one episode of a weakened EASM at Heshang Cave (Hu et al., 2008) and at Heifeng Cave; however, there is no clear record of abrupt climatic events at Sanbo Cave (Dong et al., 2010). The reasons for the inconsistent recording of these abrupt events may include the different geological archives and proxies analyzed, differences in sampling 
resolution and age uncertainty, and genuine regional climatic differences (An et al., 2012; Chen et al., 2015; Dong et al., 2010, 2015; Hu et al., 2008; Shen et al., 2005). In addition, the evidently unstable nature of the early Holocene climate in China makes it unsurprising that the abrupt climatic events were not recorded consistently across a wide geographical area and in contrasting geological archives.

Despite the evident complexity of EASM fluctuations during the early Holocene, the main trend of Holocene EASM recorded by the stalagmite $\delta^{18} \mathrm{O}$ records in the current study is similar to other EASM/precipitation records in China. This confirms the effectiveness of stalagmite $\delta^{18} \mathrm{O}$ records as an indicator of EASM change. Considering the complexity of the factors affecting the stalagmite $\delta^{18} \mathrm{O}$, the climatic significance of the stalagmite $\delta^{18} \mathrm{O}$ needs further study. However, our findings at least indicate that EASM strength/ EASM is a very important factor for stalagmites $\delta^{18} \mathrm{O}$ changes in EASM regions, but it is not the only influencing factor.

\section{Conclusions}

- We have compared 16 stalagmite $\delta^{18} \mathrm{O}$ records from 14 caves in the EASM region to try to address the controversy regarding the paleoclimatic significance of such records during the Holocene.

- The variation of a stacked Holocene stalagmite $\delta^{18} \mathrm{O}$ record $\left(\delta^{18} \mathrm{O}_{\text {syn }}\right)$ is consistent with other EASM/precipitation records from China, indicating that stalagmite $\delta^{18} \mathrm{O}$ records are recorders of changes in EASM intensity, rather than local precipitation.

- The stalagmite $\delta^{18} \mathrm{O}_{\text {syn }}$ record is relatively stable and moderately negative during 8.0-6.0 kyr B.P., with the most negative interval occurring during 8.0-7.0 kyr B.P., in the mid-Holocene. Thus, maximum strength and stability of the EASM occurred during the mid-Holocene, in accord with the classical view of a mid-Holocene Optimum in China.

- Previous studies have focused on determining whether the early Holocene EASM in China was strong or weak. However, our results indicate substantial instability of the EASM during the early Holocene, evidenced by a series of abrupt monsoon events on a centennial-millennial scale. Therefore, irrespective of the intensity, duration and stability of the monsoon, the early Holocene was not the EASM maximum or the Climatic Optimum in China.

- Episodes of abrupt strengthening/weakening of the EASM during the early Holocene are inconsistently recorded in different geological archives. This phenomenon may be the major cause of the controversies regarding the pattern of Holocene climate change in China, and it requires further investigation.

\section{Acknowledgments}

This work was supported by National Key R\&D Program of China (2016YFC0502301), grants from the National Natural Science Foundation of China (41072141, 41272192 and 41572158), and the Fundamental Research Funds for the Central Universities grants, Southwest University (XDJK2012A003). This study was 
also partially supported by the Science Vanguard Research Program of the Ministry of Science and Technology (MOST) (106-2628-M-002-013 to C.-C.S.), the National Taiwan University (105R7625 to C.C.S.), and the Higher Education Sprout Project of the Ministry of Education, Taiwan ROC (107L901001 to C.C.S.). Holocene stalagmite $\delta^{18} \mathrm{O}$, the chronological data and stacked stalagmite data used to support the findings of this study can be obtained in the supporting information file. All these data will be deposited in the World Data Center repository (https://www.ncdc.noaa.gov/data-access/paleoclimatologydata/datasets/speleothem).

\section{References}

An ZS, Porter SC, Kutzbach JE et al. (2000) Asynchronous Holocene optimum of the East Asian monsoon. Quaternary Science Reviews 19(8): 743-762.

An ZS, Colman SM, Zhou WJ et al. (2012) Interplay between the westerlies and Asian monsoon recorded in Lake Qinghai sediments since 32 ka. Scientific Reports 2(8): 619. DOI: 10.1038/srep00619.

Bond G, Kromer B, Beer J et al. (2001) Persistent solar influence on North Atlantic climate during the Holocene. Science 294(5549): 2130-2136.

Cai YJ., Zhang HW, Cheng H et al. (2012) The Holocene Indian monsoon variability over the southern Tibetan Plateau and its teleconnections. Earth and Planetary Science Letters 335-336(3): 135-144.

Cai YJ, Tan LC, Cheng H et al. (2010) The variation of summer monsoon precipitation in central China since the last deglaciation. Earth and Planetary Science Letters 291(1-4): 21-31.

Chen FH, Xu QH, Chen JH et al. (2015) East Asian summer monsoon precipitation variability since the last deglaciation. Scientific Reports 5: 11186. DOI: 10.1038/srep11186.

Chen FH, Wu D, Chen JH et al. (2016) Holocene moisture and East Asian summer monsoon evolution in the northeastern Tibetan Plateau recorded by Lake Qinghai and its environs: A review of conflicting proxies. Quaternary Science Reviews 154: 111-129.

Chen JH, Rao ZG, Liu JB et al. (2016) On the timing of the East Asian summer monsoon maximum during the Holocene-Does the speleothem oxygen isotope record reflect monsoon rainfall variability? Science China Earth Sciences 59(12): 2328-2338. DOI: 10.1007/s11430-015-5500-5.

Cheng H, Edwards RL, Wang YJ et al. (2006) A penultimate glacial monsoon record from Hulu Cave and two-phase glacial terminations. Geology 34(3): 217-220.

Cheng H, Sinha A, Wang XF et al. (2012) The Global Paleo-monsoon as seen through speleothem records from Asia and South America. Climate Dynamics 39(5): 1045-1062. DOI:10.1007/s00382-012-1363-7.

Cheng H, Edwards RL, Shen CC et al. (2013) Improvements in ${ }^{230} \mathrm{Th}$ dating, ${ }^{230} \mathrm{Th}$ and ${ }^{234} \mathrm{U}$ half-life values, and U-Th isotopic measurements by multi-collector inductively coupled plasma mass spectroscopy. Earth and Planetary Science Letters 371: 82-91.

Cheng H, Edwards RL, Sinha A et al. (2016) The Asian monsoon over the past 640,000 years and ice age terminations. Nature 534(7609): 640-646. DOI:10.1038/nature18591.

Dayem KE, Molnar P, Battisti D et al. (2010) Lessons learned from oxygen isotopes in modern precipitation applied to interpretation of speleothem records of paleoclimate from eastern Asia. Earth and Planetary Science Letters 295: 219-230.

Dong JG, Shen CC, Kong XG et al. (2015) Reconciliation of hydroclimate sequences from the Chinese Loess Plateau and low-latitude East Asian Summer Monsoon regions over the past 14,500 years. Palaeogeography, Palaeoclimatology, Palaeoecology 435(3): 127-135. 
Dong JG, Wang YJ, Cheng $\mathrm{H}$ et al. (2010) A high-resolution stalagmite record of the Holocene East Asian monsoon from Mt Shennongjia, central China. The Holocene 20(2): 257-264.

Dykoski CA, Edwards RL, Cheng H. (2005) A high-resolution, absolute-dated Holocene and deglacial Asian monsoon record from Dongge Cave, China. Earth and Planetary Science Letters 233(1-2): 71-86.

Fairchild IJ, Smith CL, Baker A et al. (2006) Modification and preservation of environmental signals in speleothems. Earth Science Reviews 75(1): 105-153.

Goldsmith Y, Broecker WS, Xu H et al. (2017) Northward extent of East Asian monsoon covaries with intensity on orbital and millennial timescales. Proc. Natl. Acad. Sci. U.S.A. 114(8): 1817-1821.

Hong YT, Hong B, Lin QH et al. (2003) Correlation between Indian Ocean summer monsoon and North Atlantic climate during the Holocene. Earth and Planetary Science Letters 211(3-4): 371-380.

Hu CY, Henderson GM, Huang JH et al. (2008) Quantification of Holocene Asian monsoon rainfall from spatially separated cave records. Earth and Planetary Science Letters 226(3-4): 221-232.

Jiang XY, He YQ, Shen CC et al. (2012) Stalagmite-inferred Holocene precipitation in northern Guizhou Province, China, and asynchronous termination of the Climatic Optimum in the Asian monsoon territory. Chinese science bulletin 57(7): 798-801. DOI: 10.1007/s11434-011-4848-6.

Johnsen SJ, Dahl-Jensen D, Gundestrup N et al. (2001) Oxygen isotope and palaeotemperature records from six Greenland ice-core stations: Camp Century, Dye-3, GRIP, GISP2, Renland and NorthGRIP. Journal of Quaternary Science 16(4): 299-307. DOI: 10.1002/jqs.622.

Johnson and Ingram (2004) Spatial and temporal variability in the stable isotope systematics of modern precipitation in China: implications for paleoclimate reconstructions. Earth and Planetary Science Letters 220(3-4): 365-377. DOI: 10.1016/S0012-821X(04)00036-6.

Laskar J, Robutel P, Joutel F et al. (2004) A long-term numerical solution for the insolation quantities of the Earth[J]. Astronomy \& Astrophysics. 2004, 428(1): 261-285.

Li HC, Gu TL, Paulsen D et al. (2000) Paleo-climatic and paleo-monsoonal variation in central China recorded by stable isotope records of stalagmites from Buddha Cave, South Shaanxi. Seismology and Geology 22(s1): 63-78 (in Chinese with English abstract).

Lu HY, Yi SW, Liu ZY et al. (2013) Variation of East Asian monsoon precipitation during the past $21 \mathrm{k} . \mathrm{y}$. and potential $\mathrm{CO}_{2}$ forcing. Geology 41(9): 1023-1026.

Maher BA. (2008) Holocene variability of the East Asian summer monsoon from Chinese cave records: a reassessment. The Holocene 18(6): 861-866. DOI: 10.1177/0959683608095569.

Paillard D, Labeyrie L, Yiou P. (1996) Macintosh program performs time-series analysis. Eos Transactions American Geophysical Union 77(39): 379-379.

Pausata FSR, Battisti DS, Nisancioglu KH et al. (2011) Chinese stalagmite $\delta 180$ controlled by changes in the Indian monsoon during a simulated Heinrich event. Nature Geoscience 4(7): 474-480. DOI:

10.1038/NGEO1169.

Shen CC, Wu CC, Cheng H et al. (2012) High-precision and high-resolution carbonate ${ }^{230}$ Th dating by MC-

ICP-MS with SEM protocols. Geochimica et Cosmochimica Acta 99(99): 71-86. DOI: 10.1016/j.gca.2012.09.018.

Shen J, Liu XQ, Wang SM et al. (2005) Paleo-climatic changes in the Qinghai Lake area during the last 18,000 years. Quaternary International 136(1): 131-140.

Shi YF, Kong ZC, Wang SM et al. (1994) Climates and environments of the Holocene Mega thermal Maximum in China. Science China Chemistry 37(4): 481-493. 
Tan LC, Cai YJ, Cheng H et al. (2009) Summer monsoon precipitation variations in central China over the past 750 years derived from a high-resolution absolute-dated stalagmite. Palaeogeography, Palaeoclimatology, Palaeoecology 280(3): 432-439.

Tan LC, Cai YJ, An ZS., Cheng, H et al.(2015) A Chinese cave links climate change, social impacts, and human adaptation over the last 500 years. Scientific Reports 5:12284. DOI: 10.1038/srep12284.

Tan M. (2009) Circulation effect: climatic significance of the short term variability of the oxygen isotopes in stalagmites from monsoonal China. Quaternary Sciences 29(5): 851-862 (in Chinese with English abstract).

Vaks A, Gutareva OS, Breitenbach SFM et al. (2013) Siberian caves recorded the history of permafrost occurrence during the past 450,000 years. Science 183-186.

Walker MJC, Gibbard PL, Berkelhammer M et al. (2014) Formal subdivision of the Holocene series/epoch. Springer International Publishing 983-987.

Wang HP, Chen JH, Zhang XJ et al. (2014) Palaeosol development in the Chinese Loess Plateau as an indicator of the strength of the East Asian summer monsoon: Evidence for a mid-Holocene maximum. Quaternary International 334-335(17): 155-164.

Wang XF, Auler AS, Edwards RL et al. (2004) Northeastern Brazil Wet Periods Linked to Distant Climate Anomalies and Rainforest Boundary Changes. Nature 432: 740-743.

Wang YJ, Cheng H, Edwards RL et al. (2008) Millennial- and orbital- scale changes in the East Asian Monsoon over the past 224,000 years. Nature 451: 1090-1093. DOI: 10.1038/nature06692.

Wang YJ, Cheng H, Edwards RL et al. (2005) The Holocene Asian monsoon: Links to solar changes and North Atlantic climate. Science 308(5723): 854-857. DOI: 10.1126/science.1106296.

Wu JY, Wang YJ, Dong JG. (2011) Changes in East Asian summer monsoon during the Holocene recorded by stalagmite $\delta^{18} \mathrm{O}$ records from Liaoning Province (in Chinese). Quaternary Research 31(6): 990-998.

Xiao JL, Si B, Zhai DY et al. (2008) Hydrology of Dali Lake in central-eastern Inner Mongolia and Holocene East Asian monsoon variability. Journal of Paleolimnology 40(1): 519-528. DOI: 10.1007/s10933-007-9179-x.

Xie SC, Evershed RP, Huang XY et al. (2013) Concordant monsoon-driven postglacial hydrological changes in peat and stalagmite records and their impacts on prehistoric cultures in central China. Geology 41(8): 827830.

Yang H, Flower RJ, Thompson JR. (2013) Sustaining China's water resources. Science 339(6116): 141-141. DOI: $10.1126 /$ science.339.6116.141-b.

Yang XL, Liu JB, Liang FY et al. (2014) Holocene stalagmite $\delta^{18} \mathrm{O}$ records in the East Asian monsoon region and their correlation with those in the Indian monsoon region. The Holocene 24(12): 1657-1664.

DOI:10.1177/0959683614551222.

Zhang HL, Yu KF, Zhao JX et al. (2013) East Asian Summer Monsoon variations in the past 12.5 ka: Highresolution $\delta^{18} \mathrm{O}$ record from a precisely dated aragonite stalagmite in central China. Journal of Asian Earth Sciences 73(8): 162-175. DOI: 10.1016/j.jseaes.2013.04.015.

Zhang N, Yang Y, Cheng H, et al., 2018. Timing and duration of the East Asian summer monsoon maximum during the Holocene based on stalagmite data from North China. The Holocene, 12:095968361878260

Zhang PZ, Cheng H, Edwards RL et al. (2008) A test of climate, sun, and culture relationships from an 1810year Chinese cave record. Science 322(5903): 940-942. DOI: 10.1126/science.1163965.

Zhou WJ, Yu XF, Jull AJT et al. (2004) High-resolution evidence from southern China of an early Holocene Optimum and a mid-Holocene dry event during the past 18,000 years. Quaternary Research 62(1): 39-48. 


\section{Figure captions}

Fig. 1. Sites with Holocene stalagmite records from the Asian summer monsoon region and locations of moisture or precipitation records from northern China mentioned in the text. The modern Asian summer monsoon limit is shown by the green dashed line.

1. Nuanhe Cave (Wu et al., 2011); 2. Lianhua Cave (Dong et al., 2015); 3. Buddha Cave (Li et al., 2000); 4. Jiuxian Cave (Cai et al., 2010); 5. Sanbao Cave (Dong et al., 2010); 6. Heshang Cave (Hu et al., 2008); 7. Lianhua Cave (Zhang et al., 2013); 8. Jinfo Cave (this study); 9. Heifeng Cave (this study); 10. Shizi Cave (this study); 11. Shigao Cave (Jiang et al., 2012); 12. Dongge Cave (Dykoski et al., 2005; Wang et al., 2005); 13. Tianmen Cave (Cai et al., 2012); 14. Dali Lake (Goldsmith et al., 2017); 15. Gonghai Lake (Chen et al., 2015); 16. Qinghai Lake (An et al., 2012); 17. Hongyuan peat bog (Hong et al., 2003) ; 18. Dongshiya Cave (Zhang et al., 2018); 19. Dahu Lake (Zhou et al., 2004).

Fig. 2. Holocene stalagmite $\delta^{18} \mathrm{O}$ records from (a) Shizi Cave (stalagmite QM09), (b) Heifeng Cave (stalagmite HF01), (c) Jinfo Cave (stalagmite J13), and (d) Jinfo Cave (stalagmite J12), from Chongqing, southwest China.

Fig. 3. Comparison of Holocene stalagmite $\delta^{18} \mathrm{O}$ records from the Chinese monsoon region.

(a) Nuanhe Cave (NH12, red; NH13, green; MH 15, blue) (Wu et al., 2011); (b) Lianhua Cave (LHD1, blue; LHD3, LT gray; LHD4, yellow; LHD9, cyan LHD5, magenta) (Dong et al., 2015); (c) Buddha Cave (SF) (Li et al., 2000); (d) Jiuxian Cave (C996-1, yellow; C996-2, blue) (Cai et al., 2010); (e) Sanbao Cave (SB 27, olive; SB10, wine; SB26, purple) (Dong et al., 2010); (f) Heshang Cave (HS4) (Hu et al., 2008); (g) Shizi Cave (QM09) (this study); (h) Heifeng Cave (HF01) (this study); (i) Jinfo Cave (J13) (this study); (j) Jinfo Cave (J13); (k) Lianhua Cave (LH2) (Zhang et al., 2013); (l) Dongge Cave (D4) (Dykoski et al., 2005); (m) Dongge Cave (DA) (Wang et al., 2005); (n) Tianmen Cave (TM18B, pink; TM18A, cyan) (Cai et al., 2012); (o) Shigao Cave (SG1, violet; SG2, orange) (Jiang et al., 2012). (p) Dongshiya Cave (DSY1, LT magenta; LM2 dark gray; DSY9 gray) (Zhang et al., 2018). The vertical grey bars indicate weak EASM events in the early and mid- Holocene. Stacked stalagmite records are shown by colors other than black; otherwise black is used.

Fig. 4. Stacked and normalized Chinese stalagmite $\delta^{18} \mathrm{O}_{\text {syn }}$ record. Black error bars indicates standard deviations.

Fig. 5 Comparison of stacked stalagmite $\delta^{18} \mathrm{O}$ records and Northern Hemisphere summer insolation. (a) Northern Hemisphere summer insolation at $65^{\circ} \mathrm{N}$ (Fig. 5a) (Laskar et al., 2004). (b) Stacked stalagmite $\delta^{18} \mathrm{O}_{\text {syn }}$ record. (c) Stacked stalagmite $\delta^{18} \mathrm{O}_{\mathrm{S}+\mathrm{N}}$ record. (d). Stacked stalagmite $\delta^{18} \mathrm{O}_{\text {North }}$ record from six caves in 
northern China: Nuanhe Cave (Wu et al., 2011), Lianhua Cave (Dong et al., 2015), Buddha Cave (Li et al., 2000), Jiuxian Cave (Cai et al., 2010), Sanbao Cave (Dong et al., 2010) and Dongshiya Cave (Zhang et al., 2018). (e) Stacked stalagmite $\delta^{18} \mathrm{O}_{\text {South }}$ record from 8 caves in southern China: Heshang Cave (Hu et al., 2008), Shizi Cave (this study), Heifeng Cave (this study), Jinfo Cave (J13) (this study), Lianhua Cave (Zhang et al., 2013), Dongge Cave (Dykoski et al., 2005; Wang et al., 2005), Tianmen Cave (Cai et al., 2012), Shigao Cave (Jiang et al., 2012). (f). Sample scores on the first principal component (PC1) of a principal components analysis of 7 integrated Holocene stalagmite records (see Fig. 3). The vertical yellow bar corresponds to an interval of weak EASM in the early Holocene

Fig. 6. Comparison of a stacked $\delta^{18} \mathrm{O}_{\text {syn }}$ stalagmite record from China with other paleoclimatic records. (a) NGRIP Greenland ice core record (Johnsen et al., 2001); (b) Hongyuan peat $\delta^{13}$ C record (Hong et al., 2003); (c) Qinghai Lake summer monsoon index (SMI). SMI is non-dimensional and increased SMI values simply represent enhanced summer monsoon intensity. (An et al., 2012); (d) Dali lake level (Goldsmith et al., 2017); (e) probability densities of paleosol dates from the Loess Plateau (Wang et al., 2014); (f) stacked synthesized $\delta^{18} \mathrm{O}$ stalagmite record from China (this study). The three vertical yellow bars indicate weak EASM events in the early Holocene that can be correlated to cold events recorded by the Greenland NGRIP paleotemperature record (Johnsen et al., 2001), and the vertical cyan bars denote the timing of the Holocene Optimum.

Fig. 7. Comparison of a stacked $\delta^{18} \mathrm{O}_{\text {syn }}$ stalagmite record (b) and Gonghai Lake Record (a, Chen et al., 2015). The vertical yellow bar corresponds to an interval of weak EASM in the early Holocene, and the vertical cyan bar corresponds to the Holocene Optimum. 


\section{Figures}

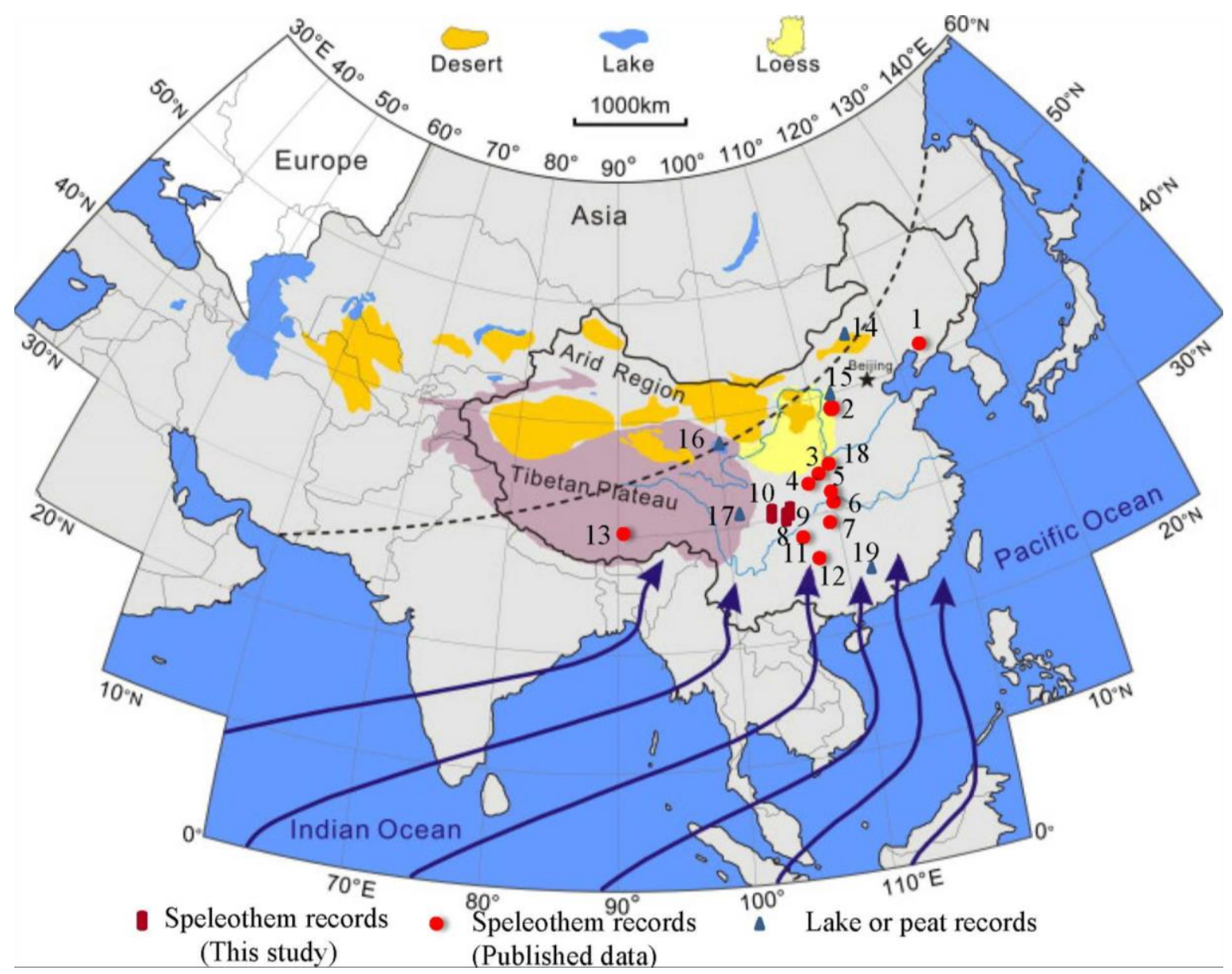

Figure 1. 


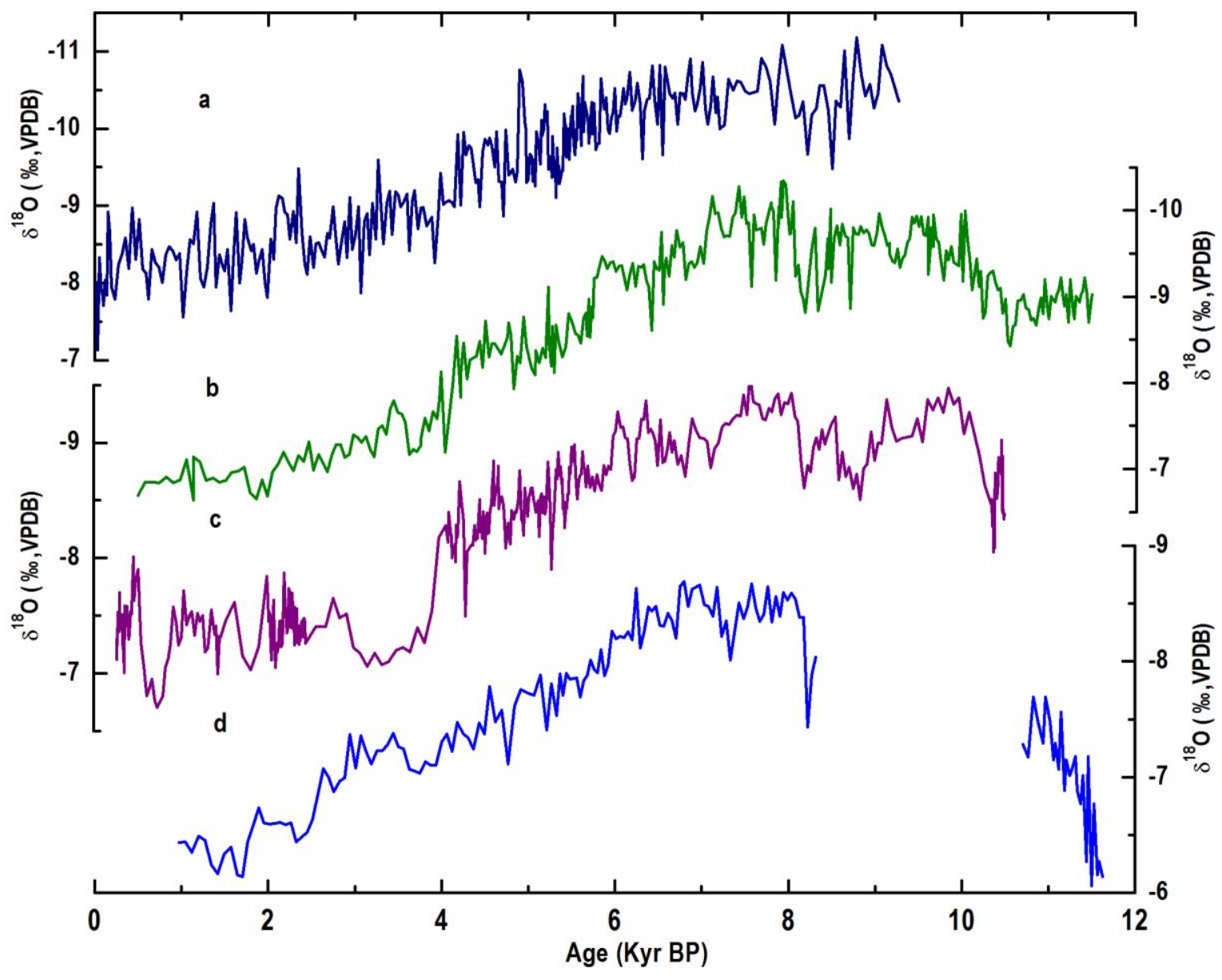

Figure 2. 


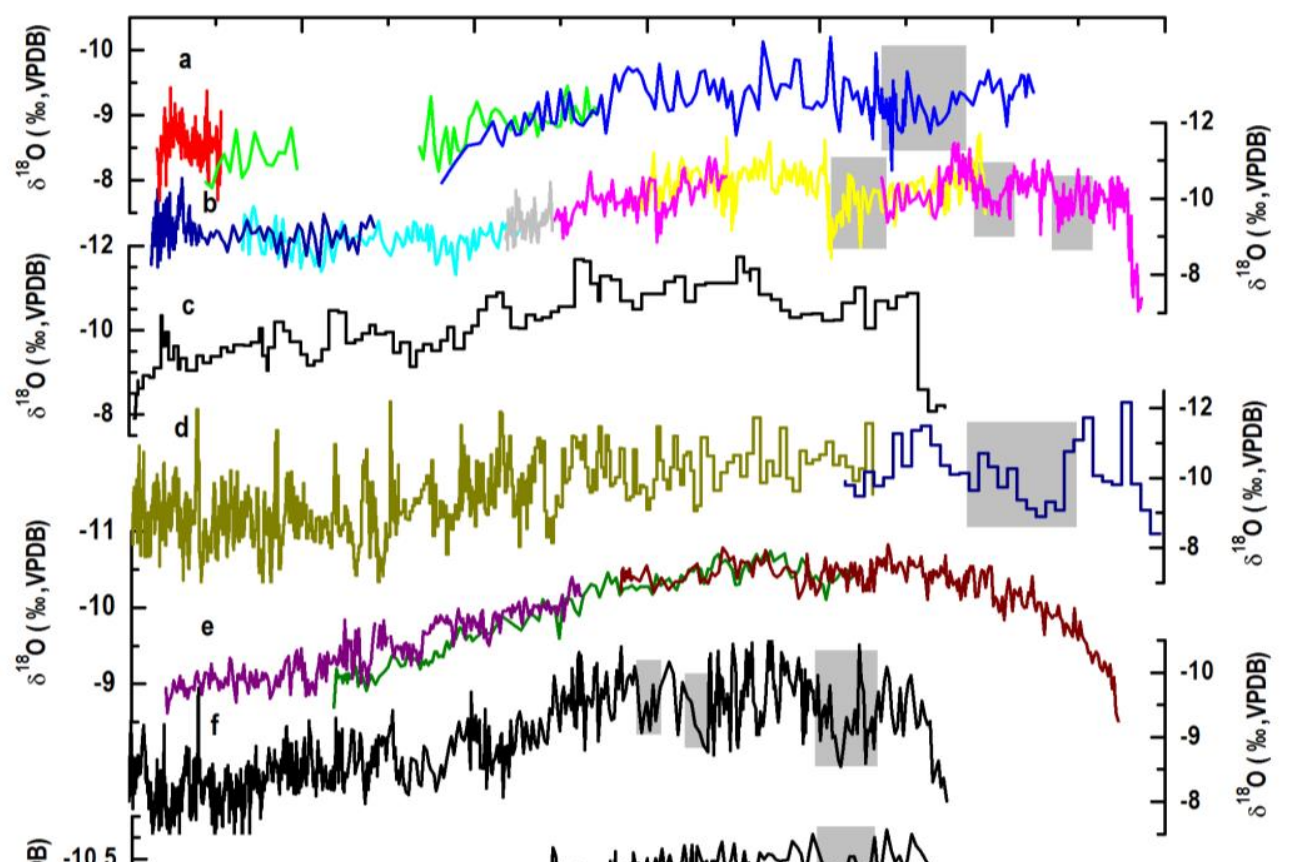

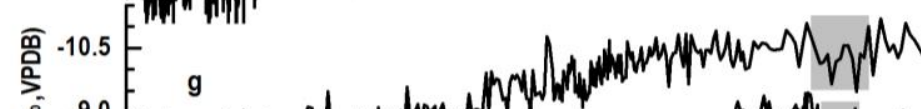

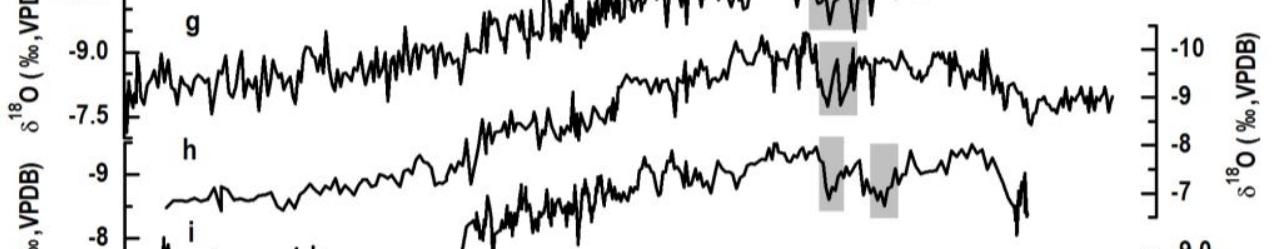

-

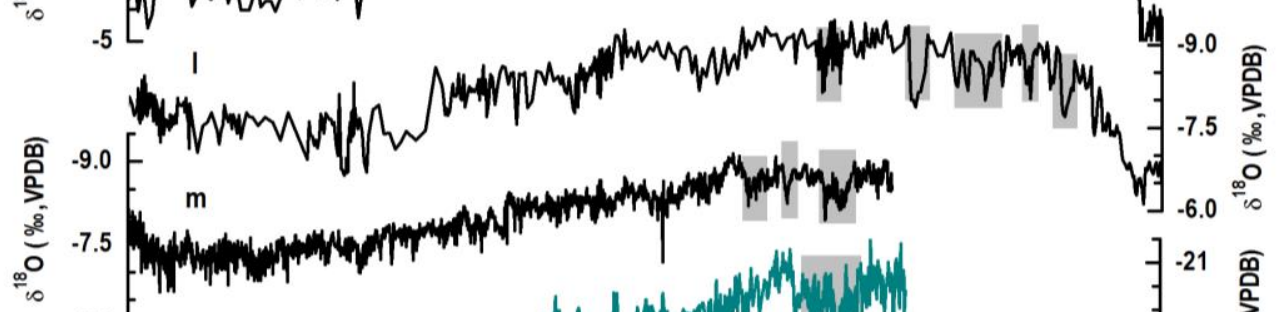

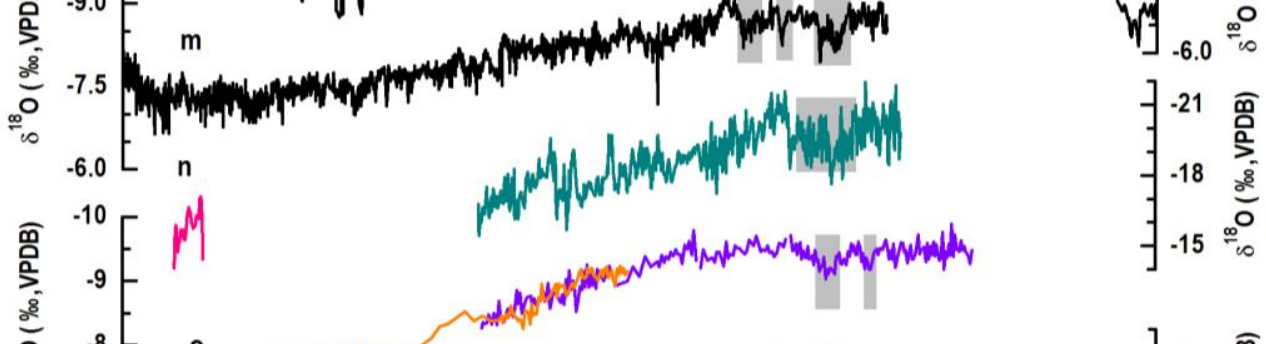

$\underbrace{2}_{0}$

Figure 3. 


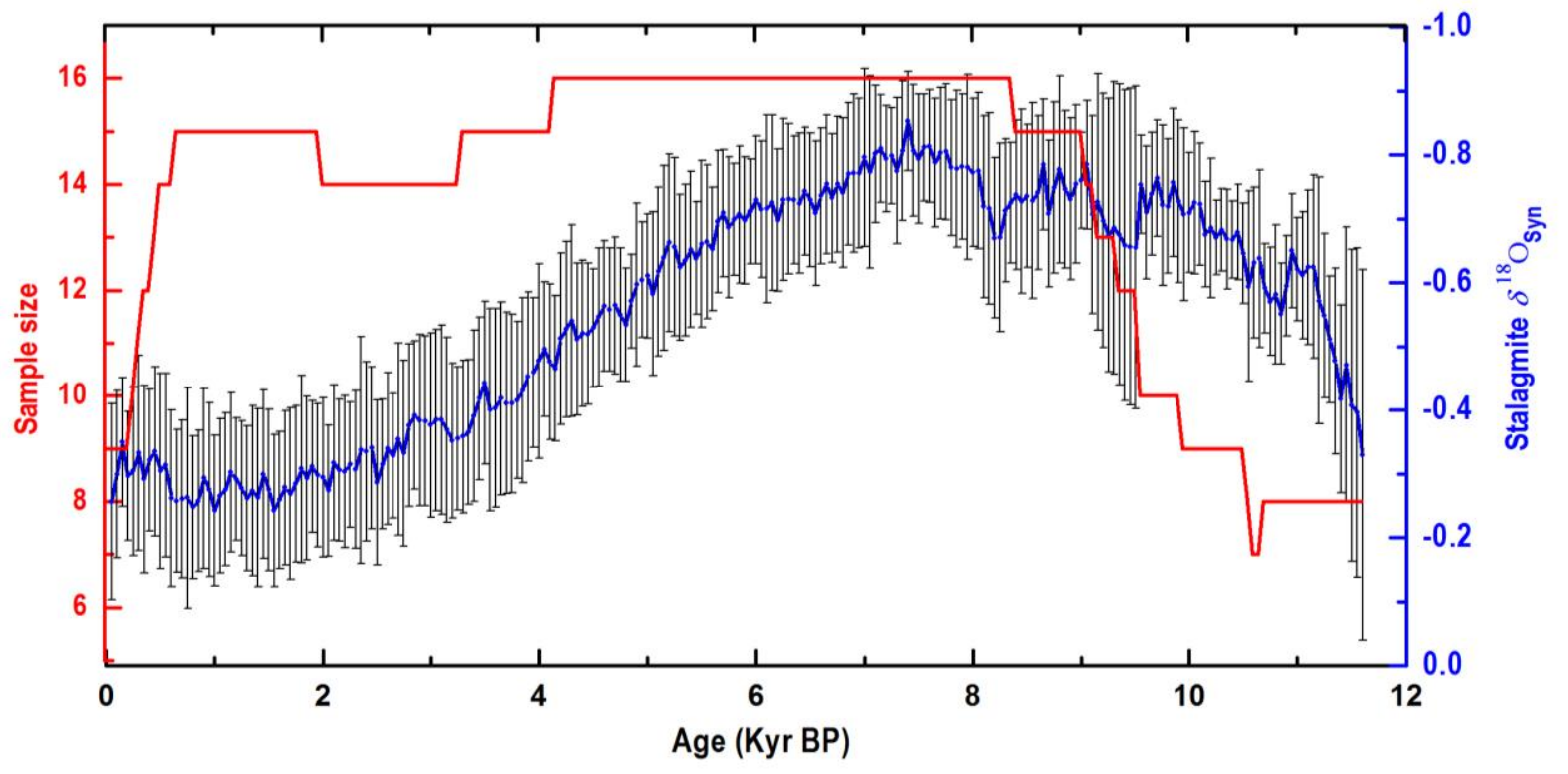

Figure 4. 


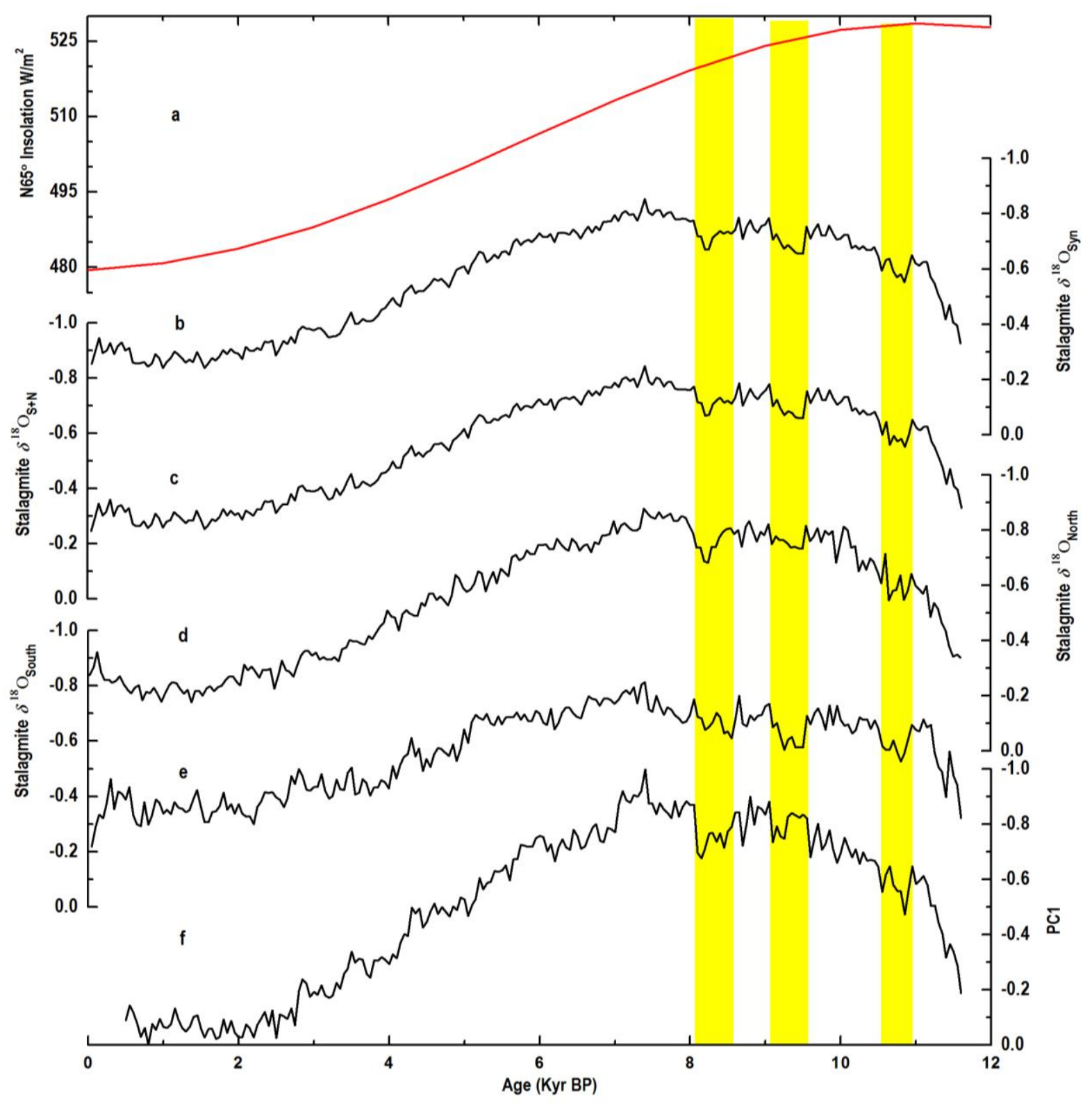

Figure 5. 


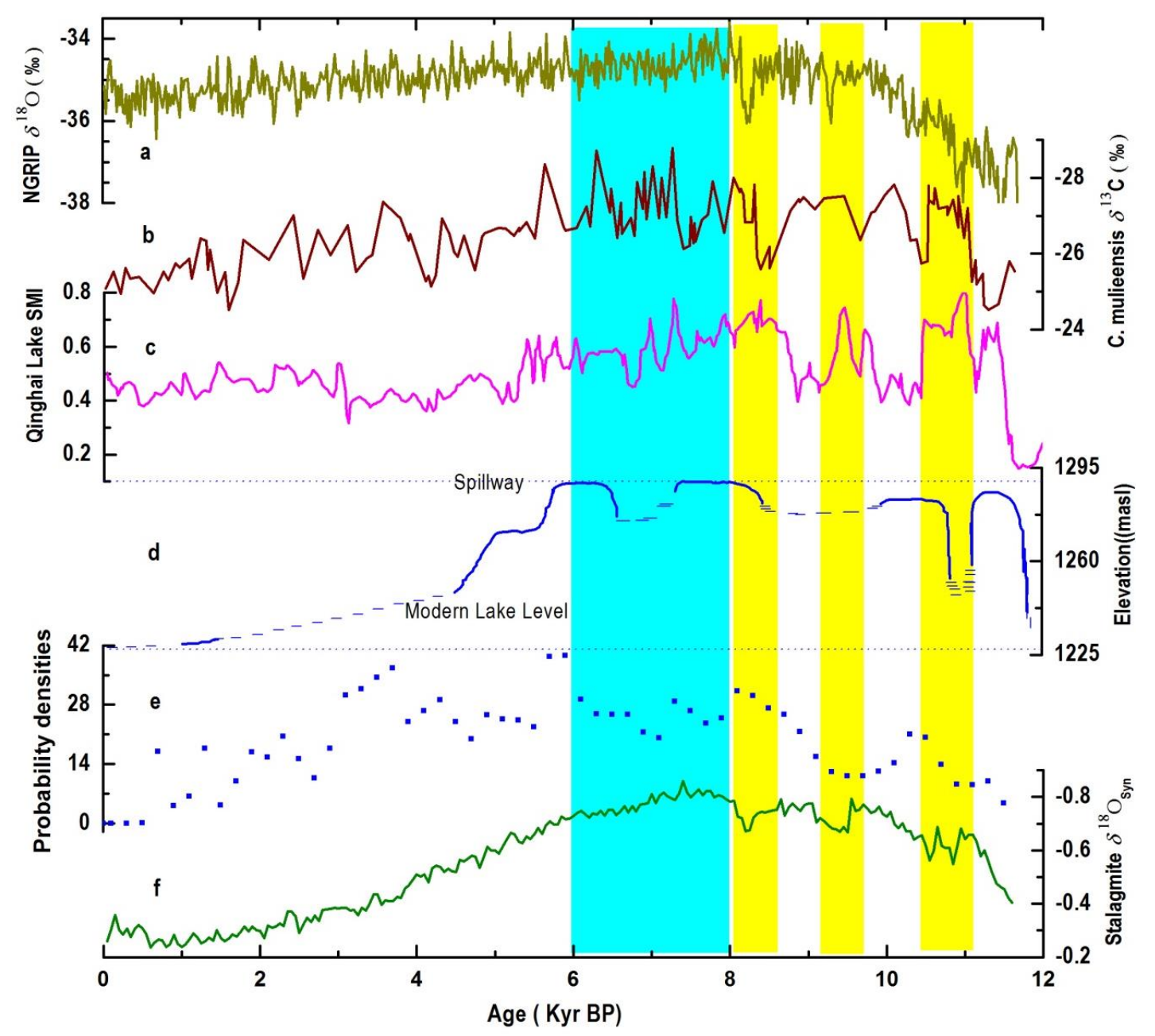

Figure 6. 


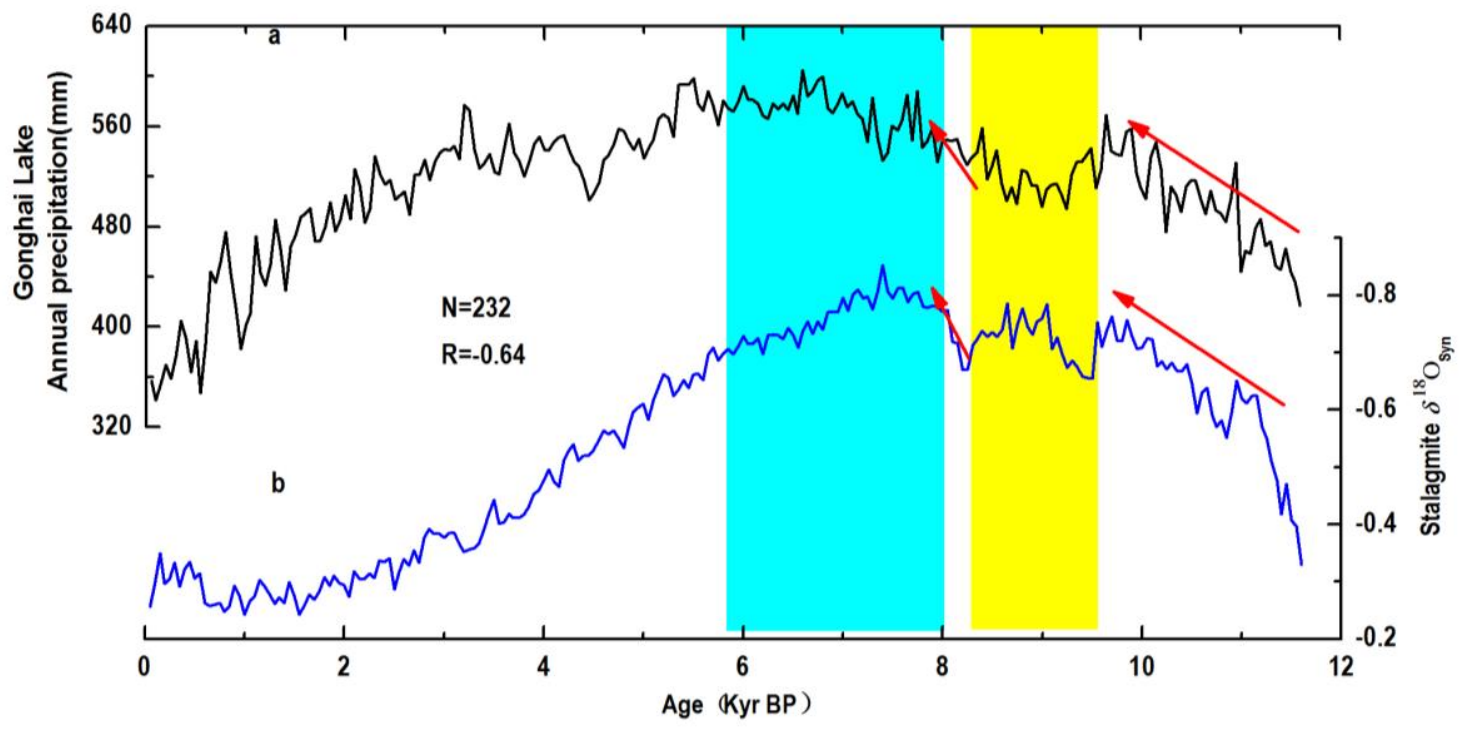

Figure 7. 